\title{
A Study of Marketing of Non-Timber Forest Products in UT of Jammu and Kashmir
}

\section{Sunish Sharma*, Sudhakar Dwivedi, Pawan Kumar Sharma, L.M. Gupta and M. Iqbal Jeelani Bhat}

Sher-e-Kashmir University of Agricultural Sciences \& Technology of Jammu (JEK), India

*Corresponding author: sunishsharma2743@gmail.com

Received: $05-10-2020$

Revised: 18-11-2020

Accepted: $11-12-2020$

\section{ABSTRACT}

The present study was conducted in Rajouri and Kishtwar district of Jammu and Kashmir state as Anardana and Kalazeera were the niche product of these areas. Four major blocks of Rajouri namely Doongi, Rajouri, Kalakote and Manjakote and two major blocks of Kishtwar namely Nagseni and Paddar were selected and fifteen farmers were selected randomly from each block constituting a sample of 60 farmers from district Rajouri and 30 farmers from district Kishtwar. A preliminary market survey was conducted in both the districts to identify the major commercial NFTPs in both the districts and it was found that Anardana (Punica granatum), Amla (Emblica officinalis Geartn.) and Guchi (Morchella esculenta) were major commercial NTFPs in Rajouri district whereas in Kishtwar district, Kalazeera (Bunium persicum) and Guchi (Morchella esculenta) were the commercially viable NTFPs. A total of three marketing channels were found in Rajouri which were farmer to consumer, farmer to village trader to wholesaler/retailer to consumer and farmer to wholesaler/retailer to consumer while the marketing channels followed by the famers of Kishtwar district for Kalazeera were farmer to consumer and farmer to wholesaler/ retailer to consumer. In case of Anardana, majority of farmers followed channel-III, while the most efficient one was channel-I (3.99) and in case of Kalazeera, the most frequent channel was channel-I which was most efficient (83.00).

Keywords: NTFP, Anardana, Kalazeera, Marketing Efficiency, Marketng channels

In India, millions of people living in and around forests subsist on collecting NTFPs; local and indigenous people usually have usufruct rights to extract NTFPs from protected areas. A significant per cent (over 50 per cent) of the revenue of the Forest Department comes from NTFP extractions and 75-80 per cent of forest export income comes from NTFP exports, and these numbers have been rising. Forests provide a large variety of tangible and intangible benefits for the people at large and are primary source of livelihood for millions of the poor people. Besides, they are also the main source of meeting food, fuel, and fodder and timber requirements of the forest dwellers. In 2013-14, forest industry contributed 1.23 per cent to India's GVA (gross value added) which is equal to ₹ 128550.00 crore at current prices and on base prices of 2011-12, the forest contributed 1.06 per cent which is equal to ₹ 96824.00 crore (Ministry of Statistics and Programme Implementation, 2015).

Most of the rural communities depend on the nontimber forest based commodities including wild edible plants to meet their food needs in periods of

\footnotetext{
How to cite this article: Sharma, S., Dwivedi, S., Sharma, P.K., Gupta, L.M. and Bhat, M.I.J. (2020). A Study of Marketing of Non-Timber Forest Products in UT of Jammu and Kashmir. Agro Economist - An International Journal, 7(2): 133-138.

Source of Support: None; Conflict of Interest: None
} 
food crisis as well as for additional food supplements. Tribes of Jammu Kashmir largely depend upon the forest commodities, which is not only a source of their food supplements, but also a great source of their income generation. Jammu Kashmir Union Territory has a geographical area of 101387 square kilometers of which the forest area is 20230 square kilometers. Jammu region of the union territory has 45.89 per cent of forest area to geographical area (Digest of Forest Statistics, 2011). Within the Jammu Kashmir Union Territory, Jammu region itself is a home to large diversity in physiographic features; cultural richness and agro-climatic variations.

There are ten districts in Jammu region and all are different from each other in topography, climate and infrastructure. Thus, Jammu region itself has the vast agricultural potential for diversifying the agriculture. Due to the variations in the agroecological situations, resource endowment and infrastructural facilities between different districts of Jammu region, the degree of diversification also varies among them.

NTFPs are crucial for development of farmers in tribal areas. NTFPs provide a wonderful opportunity for enhancing the income of people living in that area. Jammu region of Jammu Kashmir Union Territory of India has ten districts and some of the districts have considerable area under forests which falls under intermediate and temperate agro- climatic zones. Anardana and Kalazeera respectively are the two main unique crops grown in Rajouri and Kishtwar district, respectively of Jammu region. The system of marketing of these unique crops needs to be estimated for finding the importance of NTFPs. The present investigation was therefore, undertaken to analyse the marketing of non-timber forest based commodities.

\section{MATERIALS AND METHODS}

The present study was conducted in Jammu region of Jammu Kashmir Union Territory. Rajouri and Kishtwar districts were selected purposively having maximum area under Anardana and Kalazeera, respectively. Four blocks namely Manjakote, Rajouri, Doongi and Kalakote were selected from Rajouri district and two blocks namely Nagseni and Paddar were selected from district Kishtwar for the present study. Further, 15 Anardana and Kalazeera accumulators were selected, randomly from selected blocks of Rajouri and Kishtwar districts.

The primary data were collected through survey method by conducting personal interview of respondents using pretested schedule. The respective wholesalers were studied to find out the marketing purposes. The appropriate numbers of market functionaries including local traders, commission agents, weigh men, hamals, processors etc. were studied to achieve the objectives of the study. The data collected was tabulated and analyzed for examining the marketing cost, margins, price spread and the marketing efficiency.

\section{Marketing margins, costs and loss}

The post-harvest loss at various stages of marketing has been included either in the farmer's net margin or market intermediaries' margin. The modified formulae was used for separating the post harvest loss during marketing at different stages of marketing as well as for estimating the producers' share, marketing margins and marketing loss.

\section{Net farmers price}

The net farmer's price is expressed mathematically as follows

$$
\begin{aligned}
& N P_{F}=G P_{F}-\left\{C_{F}+\left(L_{F} \times G P_{F}\right)\right\} \text { or } \\
& N P_{F}=\left\{G P_{F}\right\}-\left\{C_{F}\right\}-\left\{L_{F} \times G P_{F}\right\}
\end{aligned}
$$

Where, $N P_{F}$ is net price received by the farmers (₹/ $\mathrm{kg}$ ),

$G P_{F}$ is gross price received by the farmers or wholesale price to farmers ( $₹ / \mathrm{kg}$ ), $C_{F}$ is the cost incurred by the farmers during marketing ( $(₹ / \mathrm{kg})$,

$L_{F}$ is physical loss in produce from harvest till it reaches assembly market (per Kg or per cent).

\section{Marketing margins}

The margins of market intermediaries included profit and returns, which accrued to them for storage, the interest on capital and establishment after adjusting for the marketing loss due to handling. The general expression for estimating the margin for intermediaries is given below. 
Intermediaries margin $=$

$$
\begin{gathered}
\text { Gross price } \\
\text { (sale price) }
\end{gathered}-\begin{gathered}
\text { Price paid } \\
\text { (cost price) }
\end{gathered}-\begin{gathered}
\text { Cost of } \\
\text { marketing }
\end{gathered}-\begin{gathered}
\text { Loss in value } \\
\text { during } \\
\text { wholesaling }
\end{gathered}
$$

Net marketing margin of the wholesaler is given mathematically by,

$$
\begin{aligned}
& M M_{w}=G P_{w}-G P_{F}-C_{w}-\left(L_{w} \times G P_{w}\right) \text { or } \\
& M M_{w}=\left\{G P_{w}-G P_{F}\right\}-\left\{C_{w}\right\}-\left\{L_{w} \times G P_{w}\right\}
\end{aligned}
$$

Where $M M_{w}$ is net margin of the wholesaler ₹ $/ \mathrm{kg}$ ), $G P_{w}$ is wholesaler's gross price to retailers or purchase price of retailer $(₹ / \mathrm{kg})$

$C_{w}$ is cost incurred by the wholesalers during marketing $(₹ / \mathrm{kg}), L_{w}$ is physical loss in the produce at the wholesale level (per $\mathrm{kg}$ )

$$
M M_{w}=M M_{w 1}+\ldots \ldots .+M M_{w i}+\ldots \ldots+M M_{w n}
$$

Where, $M M_{w i}$ is the marketing margin of the $i^{\text {th }}$ wholesaler. Net marketing margin of retailer is given by:

$$
\begin{aligned}
& M M_{R}=G P_{R}-G P_{W}-C_{R}-\left(L_{R} \times G P_{R}\right) \text { or } \\
& M M_{R}=\left\{G P_{R}-G P_{W}\right\}-\left\{C_{R}\right\}-\left\{L_{R} \times G P_{R}\right\}
\end{aligned}
$$

Where, $M M_{R}$ is net margin of the retailer $(₹ / \mathrm{kg})$,

$G P_{R}$ is price at the retail market or purchase price of the consumers (₹/kg), $L_{R}$ is physical loss in the produce at the retail level (per $\mathrm{kg}$ ),

$C_{R}$ is the cost incurred by the retailers during marketing (₹/kg).

The first bracketed term in equations (1), (2) and (3) indicates the gross return, while the second and third bracketed terms indicate respectively the cost and loss at different stages of marketing.

Thus, the total marketing margin of the market intermediaries (MM) is calculated as,

$$
M M=M M_{W}+M M_{R}
$$

Similarly, the total marketing cost (MC) incurred by the producer/ seller and by various intermediaries is calculated as,

$$
M C=C_{F}+C_{W}+C_{R}
$$

Total loss in the value of produce due to injury/ damage caused during handling of produce from the point of harvest till it reaches the consumers is estimated as

$$
M L=\left\{L_{F} \times G P_{F}\right\}+\left\{L_{W} \times G P_{W}\right\}+\left\{L_{R} \times G P_{R}\right\}
$$

\section{Marketing efficiency}

Most commonly used measures are conventional input to output marketing ratio, Shepherd's ratio of value (price) of goods marketed to the cost of marketing (Shepherd, 1965) and Acharya's modified marketing efficiency formula (Acharya and Agarwal, 2001). However, all these measures do not explicitly mention the loss in the produce during the marketing process as a separates item in marketing. As reduction in loss itself is one of the efficiency parameters, there has been a need to incorporate this component explicitly in the existing marketing ratios to get correct measures of marketing efficiency while comparing alternate markets/ channels. Marketing loss component was incorporated in the widely used formula as given by Acharya and Agarwal (2001) and the modified marketing efficiency (ME) formula is given below.

\section{Acharya approach}

$$
M E=\frac{N P_{F}}{M M+M C+M L}
$$

Where,

$N P_{F}$ is net price received by the farmers (₹/kg), MM is the marketing margin,

$M C$ is marketing cost,

$M L$ is marketing loss.

\section{RESULTS AND DISCUSSION}

The chain of various intermediaries/ functionaries commonly known as marketing channel comprising of agencies like farmers, traders, wholesalers/ retailers and consumers etc. help in the distribution of Anardana and Kalazeera from farmers to ultimate consumers. The marketing channels operating for Anardana in Rajouri district are: 
- Farmer - Consumer

- Farmer-Village Trader- Wholesaler / Retailer -Consumer

- Farmer-Wholesaler/Retailer-Consumer

Whereas the marketing channels operating for Kalazeera in Kishtwar district are identified as under:

- Farmer- Consumer

- Farmer -Wholesaler/Retailer-Consumer

The frequency of various marketing prevailing in the study area in the process of marketing of Anardana. Three channels are identified viz. farmer to consumer; farmer to village trader to wholesalers/retailers to consumer and farmer to wholesaler/retailer to consumer. The Table 1 revealed that $9(15 \%)$ farmers were following the channel I, $25(41.67 \%)$ farmers were following channel-II whereas majority i.e. 26 $(43.33 \%)$ number of farmers opted channel-III. A total of 3 village traders were identified, that were present only in channel-II whereas the total number of wholesaler/retailer were 5 , out of which 2 were present in channel-II and $3(40 \%)$ were in channel-III.

In the first channel, either consumer themselves use to go to take Anardana from farmers or farmers themselves go to the house of consumers to sold NTFPs (Table 1). In the second channel, village trader collects the Anardana from farmers and supplies it to wholesaler/retailer and then sold to consumers whereas in third channel farmers supplies Anardana to wholesaler/retailer, which is sold to consumer.

The frequencies of two marketing channels viz. farmer to consumer and farmer to wholesaler / retailer to consumer for the trade of Kalazeera in Kishtwar district are presented in Table 2. The table shows that majority of farmers i.e. 24 (80\%) were following channel-I for direct sale of Kalazeera to consumer whereas $6(20 \%)$ farmers were following channel-II. The table shows that $4(100 \%)$ wholesaler/ retailer are present in channel II. In second channel, farmer supplies Kalazeera to wholesaler/retailer, which is traded to consumer.

The Table 3 reveals the marketing cost, marketing margins and price spread through different three channels of marketing of Anardana under study. It depicts that marketing cost paid by the farmers comes to ₹ 51.17 per $\mathrm{kg}$ in first channel, ₹ 13.38 per $\mathrm{kg}$ in second channel and ₹ 14.43 per $\mathrm{kg}$ in channel third. The cost of marketing paid by trader comes to ₹ 3.80 per $\mathrm{kg}$ in second channel as trader involve in process of marketing in this channel only. Per $\mathrm{kg}$ cost of marketing paid by retailer comes to ₹ 5.27 and ₹ 5.22 in the second and third channel respectively as wholesaler/retailers are involved in these two channels. Per kg total cost of marketing of

Table 1: Frequency of different marketing channels followed for Anardana under different categories

\begin{tabular}{lllll}
\hline Category & $\begin{array}{l}\text { Farmer to } \\
\text { Consumer (I) }\end{array}$ & $\begin{array}{l}\text { Farmer -village trader- } \\
\text { Wholesaler/ Retailer -Consumer } \\
\text { (II) }\end{array}$ & $\begin{array}{l}\text { Farmer- Wholesaler/ } \\
\text { Retailer-Consumer } \\
\text { (III) }\end{array}$ & Total \\
\hline Farmer & $9(15.00)$ & $25(41.67)$ & $26(43.33)$ & $60(100.00)$ \\
Village Trader & $0(0.00)$ & $3(100.00)$ & $0(0.00)$ & $3(100.00)$ \\
Wholesaler/ Retailer & $0(0.00)$ & $2(40.00)$ & $3(60.00)$ & $5(100.00)$ \\
\hline Total & $\mathbf{9 ( 1 3 . 2 3 )}$ & $\mathbf{3 0 ( 4 4 . 1 7 )}$ & $\mathbf{2 9 ( 4 2 . 6 0 )}$ & $\mathbf{6 8 ~ ( 1 0 0 . 0 0 )}$ \\
\hline
\end{tabular}

Table 2: Frequency of different marketing channels followed for Kalazeera

\begin{tabular}{llll}
\hline Category & Farmer - Consumer (I) & $\begin{array}{l}\text { Farmer - Wholesaler/ Retailer- } \\
\text { Consumer } \\
\text { (II) }\end{array}$ & Total \\
\hline Farmer & $24(80)$ & $6(20)$ & $30(100)$ \\
Wholesaler/ Retailer & $0(0)$ & $4(100)$ & $4(100)$ \\
\hline Total & $\mathbf{2 4}(\mathbf{7 0 . 5 9 )}$ & $\mathbf{1 0 ( 2 9 . 4 1 )}$ & $\mathbf{3 4 ( \mathbf { 1 0 0 } )}$ \\
\hline
\end{tabular}


Anardana comes to ₹ 51.17 , ₹ 22.45 and ₹ 19.65 in channel first, channel second and third respectively. The producer's price in consumer's rupee comes to ₹ 255.55 per $\mathrm{kg}$, ₹ 272.00 per $\mathrm{kg}$ and ₹ 263.46 per $\mathrm{kg}$ in channel first channel second and channel third respectively.

Table 3: Marketing cost, Marketing margin and price spread of Anardana (₹/kg)

\begin{tabular}{|c|c|c|c|}
\hline \multirow{3}{*}{ Particulars } & \multicolumn{3}{|c|}{ Channel- Channel- Channel } \\
\hline & I & II & -III \\
\hline & ₹/kg & ₹/kg & ₹/kg \\
\hline \multicolumn{4}{|l|}{ Marketing cost (₹) } \\
\hline $\begin{array}{l}\text { Farmer's marketing } \\
\text { expenditure }\end{array}$ & 51.17 & 13.38 & 14.43 \\
\hline Trading expenditure & 0.00 & 3.80 & 0.00 \\
\hline $\begin{array}{l}\text { Retailers marketing } \\
\text { expenditure }\end{array}$ & 0.00 & 5.27 & 5.22 \\
\hline Total cost of marketing & 51.17 & 22.45 & 19.65 \\
\hline \multicolumn{4}{|l|}{ Selling price (₹) } \\
\hline Farmer & 255.55 & 272.00 & 263.46 \\
\hline Trader & 0.00 & 340.00 & 0.00 \\
\hline Retailer & 0.00 & 390.00 & 400.00 \\
\hline $\begin{array}{l}\text { Producers share in } \\
\text { consumers' rupee }(\%)\end{array}$ & 79.33 & 58.04 & 57.15 \\
\hline \multicolumn{4}{|c|}{ Absolute marketing margin (₹) } \\
\hline Trader & 0.00 & 105.43 & 0.00 \\
\hline Retailer & 0.00 & 74.73 & 114.78 \\
\hline Total & 0.00 & 180.16 & 114.78 \\
\hline \multicolumn{4}{|c|}{ Percentage marketing margin } \\
\hline Trader & 0.00 & 16.67 & 0.00 \\
\hline Retailer & 0.00 & 16.66 & 14.28 \\
\hline Total & 0.00 & 33.33 & 14.28 \\
\hline \multicolumn{4}{|l|}{ Percentage marketing cost } \\
\hline Farmer & 11.11 & 4.00 & 3.84 \\
\hline Trader & 0.00 & 16.67 & 0.00 \\
\hline Retailer & 0.00 & 16.60 & 20.00 \\
\hline Total & 11.11 & 37.27 & 23.84 \\
\hline
\end{tabular}

The marketing cost paid by the farmers comes to ₹ 45.39 per $\mathrm{kg}$ in first channel and ₹ 89.47 per $\mathrm{kg}$ in channel second. Per $\mathrm{kg}$ cost of marketing paid by retailer comes to ₹ 13.69. Whereas per $\mathrm{kg}$ total cost of marketing of Kalazeera comes to ₹ 45.39 and ₹ 103.16 in channel first, and channel second respectively. The producer's price in consumer's rupee comes to ₹ 3812.50 per $\mathrm{kg}$ and ₹ 2916.67 per $\mathrm{kg}$ in channel first and channel second respectively (Table 4).
Table 4: Marketing cost, marketing margin and price spread of Kalazeera ( $₹ / \mathrm{kg})$

\begin{tabular}{|c|c|c|}
\hline \multirow[t]{2}{*}{ Particulars } & \multicolumn{2}{|c|}{$\begin{array}{c}\text { Channel- Channel- } \\
\text { I }\end{array}$} \\
\hline & ₹/kg & $₹ / k g$ \\
\hline \multicolumn{3}{|l|}{ Marketing cost } \\
\hline Farmers' marketing expenditure & 45.39 & 89.47 \\
\hline Trading expenditure & 0.00 & 0.00 \\
\hline Retailers marketing expenditure & 0.00 & 13.69 \\
\hline Total cost of marketing & 45.39 & 103.16 \\
\hline \multicolumn{3}{|l|}{ Selling price } \\
\hline Farmer & 3812.50 & 2916.67 \\
\hline Trader & 0.00 & 0.00 \\
\hline Retailer & 0.00 & 3175 \\
\hline $\begin{array}{l}\text { Producers share in consumers' } \\
\text { rupee }(\%)\end{array}$ & 98.50 & 79.55 \\
\hline \multicolumn{3}{|l|}{ Absolute marketing margin } \\
\hline Trader & 0.00 & 0.00 \\
\hline Retailer & 0.00 & 986.31 \\
\hline Total & 0.00 & 986.31 \\
\hline \multicolumn{3}{|l|}{ Percentage marketing margin } \\
\hline Trader & 0.00 & 0.00 \\
\hline Retailer & 0.00 & 25.00 \\
\hline Total & 0.00 & 25.00 \\
\hline \multicolumn{3}{|l|}{ Percentage marketing cost } \\
\hline Producer & 4.16 & 22.17 \\
\hline Trader & 0.00 & 0.00 \\
\hline Retailer & 0.00 & 25.00 \\
\hline Total & 4.16 & 47.17 \\
\hline
\end{tabular}

Marketing efficiency is the effectiveness with which the market performs its designated functions. The Table 5 revealed the marketing efficiency of Anardana marketing under three different channels identified in the present study.

Table 5: Marketing efficiency of different channels of Anardana (₹/kg)

\begin{tabular}{|c|c|c|c|}
\hline Particulars & $\begin{array}{c}\text { Channel } \\
\text { I } \\
\text { (₹) }\end{array}$ & $\begin{array}{c}\text { Channel } \\
\text { II } \\
\text { (₹) }\end{array}$ & $\begin{array}{c}\text { Channel } \\
\text { III } \\
\text { (₹) }\end{array}$ \\
\hline $\begin{array}{l}\text { Consumers' price/price } \\
\text { received by retailer }\end{array}$ & 255.55 & 390.00 & 400.00 \\
\hline $\begin{array}{l}\text { Net price received by } \\
\text { producers }\end{array}$ & 204.37 & 258.61 & 249.02 \\
\hline Net marketing margin & 0.00 & 180.16 & 114.78 \\
\hline Marketing cost & 51.17 & 22.45 & 19.65 \\
\hline $\begin{array}{l}\text { Total marketing cost and } \\
\text { margin }\end{array}$ & 51.17 & 202.61 & 134.43 \\
\hline Marketing efficiency & 3.99 & 1.28 & 1.85 \\
\hline
\end{tabular}


The marketing efficiency was estimated using Acharya's Modified Marketing Efficiency formula. The marketing efficiency index was found maximum in channel-I (3.99) when Anardana was sold directly to consumer. When the produce was sold through intermediaries, the marketing efficiency was lower as it was 1.28 in channel- II and 1.85 in channel-III.

The marketing efficiency of Kalazeera marketing under two different channels is presented in Table 6. The marketing efficiency was estimated using Acharya's Modified Marketing Efficiency formula. The marketing efficiency was found maximum in channel-I (83.00) when Kalazeera was sold directly to consumer whereas it was only in second channel.

Table 6: Marketing efficiency of different channels of Kalazeera $(₹ / \mathrm{kg})$

\begin{tabular}{lcc}
\hline Particulars & $\begin{array}{c}\text { Channel I } \\
\text { (₹) }\end{array}$ & $\begin{array}{c}\text { Channel II } \\
\text { (₹) }\end{array}$ \\
\hline $\begin{array}{l}\text { Consumers' price/price } \\
\text { received by retailer }\end{array}$ & 3812.5 & 3175.00 \\
$\begin{array}{l}\text { Net price received by } \\
\text { producers }\end{array}$ & 3767.10 & 2827.19 \\
$\begin{array}{l}\text { Net marketing margin } \\
\text { Marketing cost }\end{array}$ & 00.00 & 986.31 \\
$\begin{array}{l}\text { Total marketing cost and } \\
\text { margin }\end{array}$ & 45.39 & 103.16 \\
Marketing efficiency & 85.39 & 1089.47 \\
\hline
\end{tabular}

\section{CONCLUSION}

Three marketing channels were found in Rajouri which were farmer to consumer, farmer to village trader to wholesaler/retailer to consumer and farmer to wholesaler/retailer to consumer while the marketing channels followed by the famers of Kishtwar district for Kalazeera were farmer to consumer and farmer to wholesaler/retailer to consumer. In case of Anardana, majority of farmers followed channel-III, while the most efficient one was channel-I and in case of Kalazeera, the most frequent channel was channel-I which was most efficient. The producer's price in consumer's rupee for Anardana comes to ₹ 255.55 per $\mathrm{kg}$, ₹ 272.00 per $\mathrm{kg}$ and ₹ 263.46 per $\mathrm{kg}$ in channel first channel second and channel third respectively whereas the producer's price in consumer's rupee for kalazeera comes to ₹ 3812.50 per $\mathrm{kg}$ and ₹ 2916.67 per $\mathrm{kg}$ in channel first and channel second respectively.

\section{REFERENCES}

Digest of Forest Statistics. 2011. J\&K Forest Department, Government of Jammu \& Kashmir.

Gaikwad, N.S. and Tilekar, S.N. 1994. Marketing of Pomegranates. Agrilutural Marketing, 37(3): 25-26.

Giri, T.K., Mazumdar, A. and Suntra, S.C. 2005. Major NTFP items and their marketing potentials at Hazaribagh forest area in Jharkhand - A case Study. Indian Forester, 131(3): 425-436.

Marothia, O.K. and Gauraha, A.K. 1992. Marketing of Denationalised Minor Forest Products in Tribal Economy. Indian Journal of Agricultural Marketing, 6(2): 84-91.

Masih, S.K., Sharma, C.B. and Sharma, M.C. 2001. NTFP and their price trends in primary tribal markets. Journal of Non-timber Forest Products, 8(3/4): 159-168.

Ministry of Statistics and Programme Implementation, Planning Commission, Government of India. 2015. Sector-wise contribution of GDP of India.

Muraleedharan, P.K., Anitha, V., Seethalakshmi, K.K., Sasidharan, N. and Sreenivasan, M.A. 1999. Marketing of non-wood forest products in Kerala: Price spread and economy efficiency. Journal of Non-Timber Forest Products, 6(3/4): 103-109.

Singh, D.V., Sharma, D.N. and Verma, R.L. 1992. Production and marketing of minor forest products: A study in Himachal Pradesh. Indian Journal of Agricultural Marketing, 6(2): 92-96.

Singh, R.S. 1992. Marketing of Anardana (Wild Pomegranate) in a hill district of Jammu region. Indian Journal of Agricultural Marketing, 6(2): 109-110.

Sundaravaradarajan, K.R. and Jagmohan, K.R. 2002. Marketing Cost, Margin, Price Spread and Marketing Efficiency of Cashew in Tamil Nadu. Agricultural Situation in India, 59(1): 9-16.

Terver, N.T., Tyonzughul, O.J., Aondoaseer, B.J. 2014 Prioritization and cost and returns analyses of selected non-timber forest products in Yobe State, Nigeria. Academic Journals, 6(12): 481-489. 